\section{Medical decisions are not just about facts: What a life-threatening virus can teach us about empathy, psychology, and the practice of neurology}

Nitin K. Sethi, MD, New York-Presbyterian Hospital: A patient with glioblastoma multiforme was referred to me for management of his seizure disorder. After a subtotal resection, he had undergone and failed concurrent temozolomide and radiation therapy. Recent scans showed disease progression, so treatment with bevacizumab was planned. Seizures were controlled on levetiracetam. As we approached the end of the patient interview, his wife suddenly beseeched: "Dr. Sethi, what would you do if this was your brother or father?" Confidently I reassured them that everything had been done as per existing protocol. I was, however, acutely aware that this was not, in fact, what I would have advised my family member. Cognizant of the dismal prognosis and potential toxicity of largely experimental chemotherapy, I would have counseled to opt out of further treatment.

Practicing patient-centered neurology is difficult in today's world of evidence-based medicine. While practice parameters, treatment protocols, and guidelines are invaluable in unifying and maintaining standard of care, they bypass important determinants of patients' overall health and quality of life. Addressing the emotional needs of patients and their loved ones has been delegated to palliative care specialists, to whom patients are referred when nothing more can be done. Indeed, medical decisions are not just about facts. ${ }^{1}$

Disclosures: N. Sethi is an Associate Editor for The Eastern Journal of Medicine.

Correspondence to: sethinitinmd@hotmail.com

Author Responds: Norman J. Kachuck, MD, USC Keck School of Medicine, Los Angeles: Thank you for your comment and the central question you pose: is there an ethical conundrum when what you feel must be provided as medical advice won't pass your personal moral litmus test? As you relate, the care you "confidently" assured the patient's family is appropriate may conform to community standard, but would not be your choice for you or your family. The wisdom is in the next iterative steps. With the realization that, for some deep psychological reason, you maintain different measures of success-one for your loved ones, one for everyone else-can you return to the patient with a more clear explication of how quality of life decisions on palliative care involve feelings and values - theirs and yourswhich are complex, personal, and demand a relational process to arrive at a consensus on their rectitude and sagacity? How do we share such material with our patients (or our own families), as we grapple with what it means to live, and leave, the "eudaemonic" good life? I suggest that a special task of the physician, beyond advising and administering, is to become the messenger to patients of the lesson that this critical existential question demands we all confront.

Disclosures: See original article for full disclosure list.

Correspondence to: nkachuck@me.com

1. Kachuck NJ. Medical decisions are not just about facts: what a life-threatening virus can teach us about empathy, psychology, and the practice of neurology. Neurol Clin Pract 2012;2:122-128. 


\title{
Neurology Clinical Practice
}

\author{
Medical decisions are not just about facts: What a life-threatening virus can teach us \\ about empathy, psychology, and the practice of neurology \\ Nitin K. Sethi and Norman J. Kachuck \\ Neurol Clin Pract 2012;2;171 \\ DOI 10.1212/CPJ.0b013e31826a3405
}

This information is current as of September 17, 2012

$\begin{array}{ll}\begin{array}{l}\text { Updated Information \& } \\ \text { Services }\end{array} & \begin{array}{l}\text { including high resolution figures, can be found at: } \\ \text { http://cp.neurology.org/content/2/3/171.full.html }\end{array} \\ \text { References } & \begin{array}{l}\text { This article cites } 1 \text { articles, } 1 \text { of which you can access for } \\ \text { http://cp.neurology.org/content/2/3/171.full.html\#\#ref-lis }-1\end{array} \\ \text { Permissions \& Licensing } & \begin{array}{l}\text { Information about reproducing this article in parts (figures, } \\ \text { its entirety can be found online at: } \\ \text { http://cp.neurology.org/misc/about.xhtml\#permissions }\end{array} \\ \text { Reprints } & \begin{array}{l}\text { Information about ordering reprints can be found online: } \\ \text { http://cp.neurology.org/misc/addir.xhtml\#reprintsus }\end{array}\end{array}$

Neurol Clin Pract is an official journal of the American Academy of Neurology. Published continuously since 2011, it is now a bimonthly with 6 issues per year. Copyright Copyright $\odot 2012$ by AAN Enterprises, Inc.. All rights reserved. Print ISSN: 2163-0402. Online ISSN: 2163-0933.

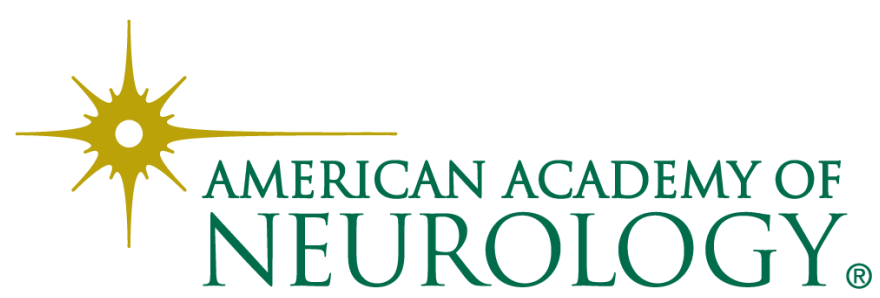

